\title{
OPTIMIZATION OF THE HYDRAULIC SYSTEM OF THE STORAGE RESERVOIR HYDRAULICALLY UNLOADING THE SEWAGE NETWORK
}

\author{
OPTYMALIZACJA UKŁADU HYDRAULICZNEGO ZBIORNIKA \\ RETENCYJNEGO ODCIĄŻAJĄCEGO HYDRAULICZNIE \\ SIEĆ KANALIZACYJNA
}

\begin{abstract}
Sewage networks together with cooperating objects are among the most capital-intensive investments, which are made within the framework of construction and development of technical infrastructure of the cities. Nowadays this issue becomes more and more important, as the development of the cities is directed at increasing territorial scope or concentration of urban areas, what causes the increase of sealing degree of cities. It influences the intensification of rainwater runoff to the sewage systems, which often do not have adequate flow capacity for discharging excess of wastewater. During intensive precipitation periods hydraulic overloads may occur, which very often result in waterlogging of the city and buildings as well as road traffic congestions. These increasing problems may be reduced by applying storage reservoirs. The main problem in designing retention reservoirs, which due to the high capacities require substantial expenditures, is the selection of their optimal hydraulic system. Very often for such a choice a number of contradictory criteria should be taken into account. Among the most important are: expenditures incurred for investment, costs of maintenance and exploitation of reservoir, upkeep expenses, technical possibilities of applying various storage reservoirs solutions and their hydraulic influence on sewerage systems and receiving waters. In the article the problem of optimization of storage reservoir Czuwaj located within combined sewage network of Zasanie quarter in Przemyśl city was solved. Due to the fact that left-bank part of the city experiences higher hydraulic overloads of sewage network some actions were taken in order to decrease frequency of these negative phenomena. Concept of sewage system extension and modernization was worked out. It includes the use of storage reservoirs within the network (such as Czuwaj reservoir), which relieve hydraulically the sewage network. In order to choose the optimal hydraulic system of Czuwaj storage reservoir optimization models of chosen gravity-pump reservoirs were developed. The lowest costs (Life Cycle Cost) of storage reservoir construction and functioning constituted the criterion for choosing the hydraulic system of Czuwaj reservoir.
\end{abstract}

Keywords: storage reservoirs, sewage networks, optimization

\footnotetext{
${ }^{1}$ Department of Infrastructure and Sustainable Development, Faculty of Civil and Environmental Engineering, Rzeszow University of Technology, al. Powstańców Warszawy 12, 35-959 Rzeszów, Poland, phone +48 1786511 51, fax +48 17865 1172, email: daniels@prz.edu.pl

*Corresponding author: stec_aga@prz.edu.pl
} 


\section{Introduction}

Wastewater systems along with facilities interacting with them are some of the most capital-intensive investments that are set up as part of the construction and development of technical infrastructure of cities. Nowadays, this issue is becoming increasingly important as urban development is focused on the expansion of the territory or increasing the density of the existing buildings, which leads to greater sealing of the surface area [1, 2]. Rainwater from areas in which previously soaked into the ground is now collected and transported to inlets in the streets. This affects the intensification of rain water runoff to sewer systems, which often do not have adequate hydraulic capacity to drain excess water [3].

Intensification of rainwater outflow has an adverse affect on soil-water relations and the quality of surface water which receives the rainwater [4-10]. This problem applies in particular to sewer systems that operate in most cities around the world [11-13].

These escalating problems can be mitigated through the use of modern and rational management of water and wastewater, which according to the guidelines of the Water Framework Directive of the European Union should be based primarily on the philosophy of sustainable development [14]. Around the world systems are used, the main objective of which is to reduce the adverse effects of urbanization on rain water management in urban areas, including LID (Low Impact Development), SUDS (Sustainable Urban Drainage Systems) and WSUD (Water Sensitive Urban Design) [15, 16].

In line with the idea of sustainable development measures should be taken primarily to reduce the size of rainwater runoff through the use of various forms of reservoirs and infiltration into the soil. In practice, this includes the use of ditches and infiltration basins, infiltration boxes and chambers, green roofs, and most of all retention and infiltration reservoirs [17-19].

Reservoirs are an integral part of modern sewage systems. They are used in the process of regulating the flow of rain water and combined sewage to the sewage network and to reduce wave discharges to protect the waters of the receiver. Reservoirs allow the capture of flow at peak times and temporary retention of excess rain water and its gradual drainage to the network located below the tank or receiver.

There are many designs of reservoirs, which can be attributed to three main groups based on the method of hydraulic configuration of the retention chamber. They are hydraulic gravity, gravity-pump and gravity-vacuum $[20,21]$. The choice of the best variant of reservoir for the known local conditions should be based on a comprehensive technical and economic analysis of different investment ideas.

Such a large variety of design solutions for reservoirs can cause problems for both developers and investors in selecting the best design concept. Examples of investments show that a lack of appropriate decision-making tools very often leads to the selection of an inefficient implementation of a financial concept. The result may be a wasteful use of resources. Given the size of the expenditure which is incurred for municipal investments it is highly recommended to use a systematic approach to the problem of decision-making and to choose the optimal design solutions for these installations.

Up to now, the optimization process has been used mainly in the design and construction of sewerage systems themselves, without facilities such as reservoirs. The first work on the optimization of wastewater systems appeared as early as the 1960s [22, 
23]. However, due to defects in the optimization models developed they have no use in engineering practice.

In subsequent years, thanks to the development of computer technology, measures were taken to develop improved methods for optimizing the design of sewerage systems and facilities interacting with them, including genetic algorithms [24-26].

$\mathrm{Fu}$ et al conducted research on the use of multi-criteria optimization in the integrated control and monitoring of sewerage systems, in which reservoirs were located [27, 28]. In this study an optimal method was developed for allocating the volume of combined sewage discharged into reservoirs, water treatment plants and directly to the receiver. The objective function was the cost of building the reservoir and the water quality of the receiver, especially in terms of their content of ammonium ions and dissolved oxygen. However, these studies did not include the selection of the optimum hydraulic tank. They focused only on the relevant section of the volume of waste water in the context of protection of water for the receiver.

This article analyzes the operation of the sewage system of the city of Przemysl and the optimized hydraulic system for the reservoir Czuwaj, whose construction is planned with the aim of relieving the hydraulic load of the existing sewerage network.

\section{Formulation of the problem}

Przemysl is located in the south-eastern part of Poland in the valley of the San River, which divides the city into the right and left bank. The city is characterized by very diverse topographic conditions that have a decisive impact on the functioning of the sewage system of the city.

The sewage system of the city of Przemysl is mainly based on a combined sewage and distribution system. Wastewater from the city area is transported by gravity main collectors located on both sides of the River San to the municipal sewage treatment plant. From the left bank of the river San basin in the district of Zasanie the waste is discharged under pressure to the other side of the river using a pumping station with a maximum capacity of $900 \mathrm{dm}^{3} / \mathrm{s}$, which works together hydraulically with a storm overflow. Then, when it is combined with the right-bank collector, it is directed to the treatment plant. Furthermore, in the city's sewer system there are local discharges of storm overflows into adjacent streams and creeks.

On a substantial length of the sewerage network, especially on the route of the flow collector situated in close proximity to the River San, there is a large hydraulic overload, which in heavy rain causes flooding and pressure operation of the network [29, 30].

In view of the fact that in the left-bank part of the city there is a hydraulic overload of the sewage system, measures were taken to reduce the incidence of these adverse events. On behalf of the Water and Sewage Company in Przemysl a concept has been developed to extend and modernize the sewerage system incorporating the use in this system of reservoirs hydraulically relieving the sewer network [31]. There was, however, no selection of the optimal hydraulic reservoir which would determine the lowest costs over the period of construction and operation of the sewer system. As a result, the algorithm formulated by Stec for the optimal choice of reservoir design was used, which allowed for the actual investment conditions the selection of hydraulic system of the tank which is characterized by the lowest Life Cycle Cost. 


\section{Analysis of the hydraulic conditions of the sewer system}

In order to analyze the hydraulic conditions of the sewer system of the Zasanie district of the city of Przemysl and to determine the required storage capacity of the reservoir, a hydrodynamic model was used, which was developed with the help of the Storm Water Management Model (SWMM) [32].

Figure 1 shows a model, developed in the SWMM, analyzing the Zasanie catchment area developed taking into account the Czuwaj reservoir. Due to the altitude layout of the existing sewerage network only a reservoir with a gravity-pump hydraulic system of accumulation chambers can be designed.

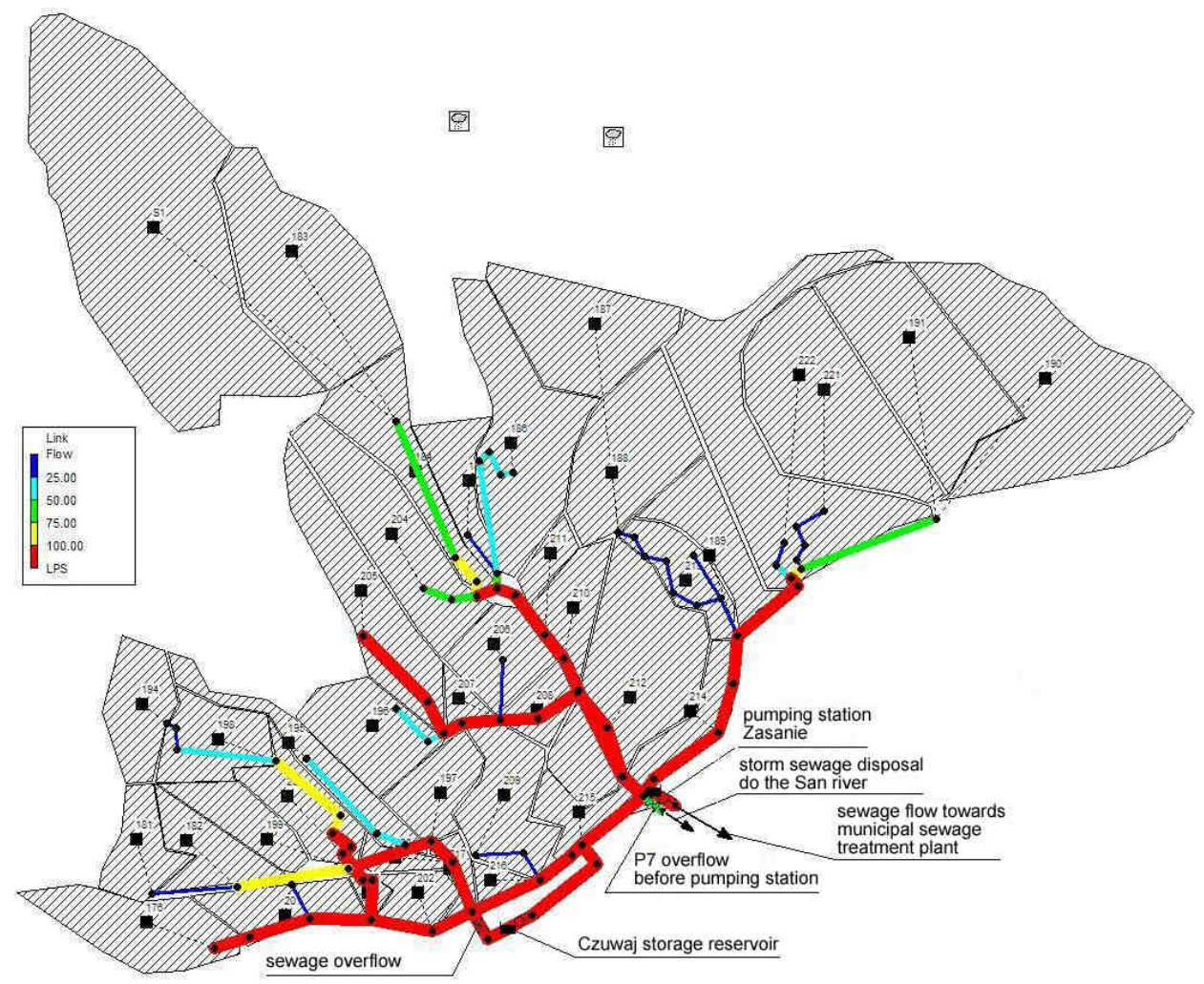

Fig. 1. Scheme of the modeled Zasanie quarter in Przemysl with the main elements of the sewage system marked

In the study an analysis was performed of the impact of the Czuwaj reservoir on the operation of the sewer system of the Zasanie district. Results of a simulation conducted on the hydrodynamic model of the district have confirmed the validity of its construction. Figure 2 presents the results of calculations of filling the main channels of the sewage system in the existing state for the selected precipitation of 3 July 2006. The flow of water in channels for intense precipitation occurs at pressure. 


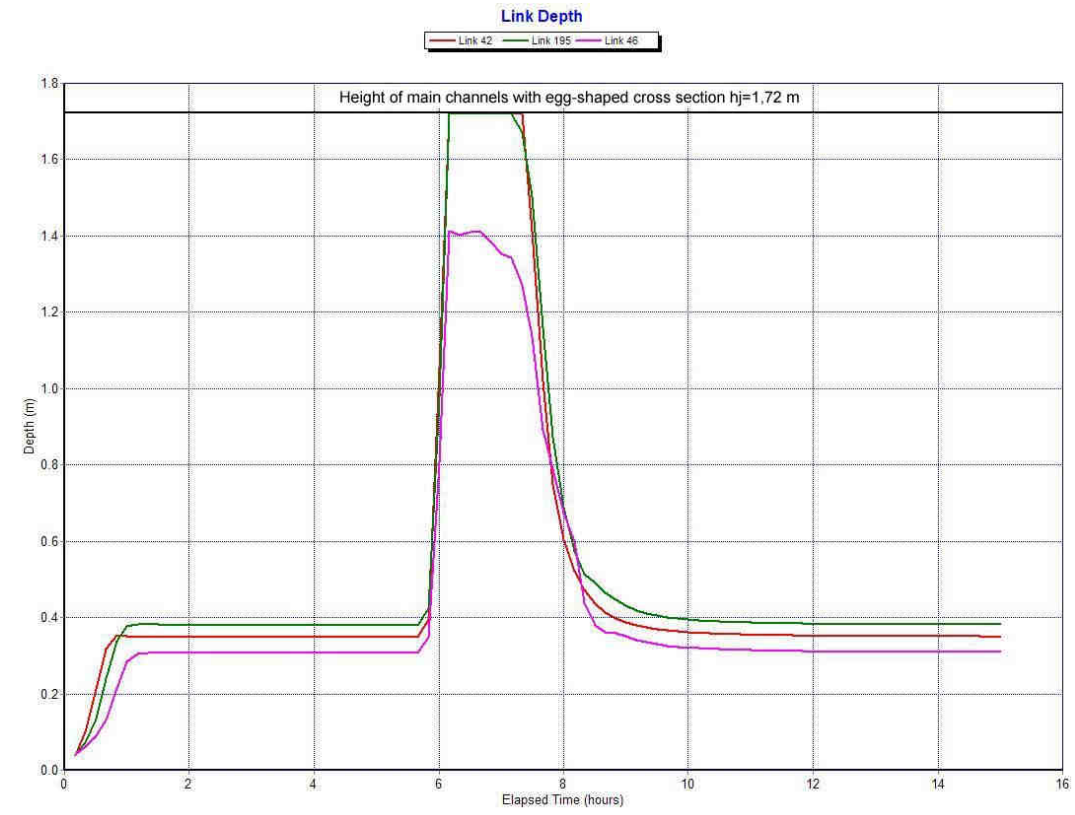

Fig. 2. Level of sewage in main canals, situated along the San river, estimated for the precipitation from 03.07.2006 - sewage system in current state

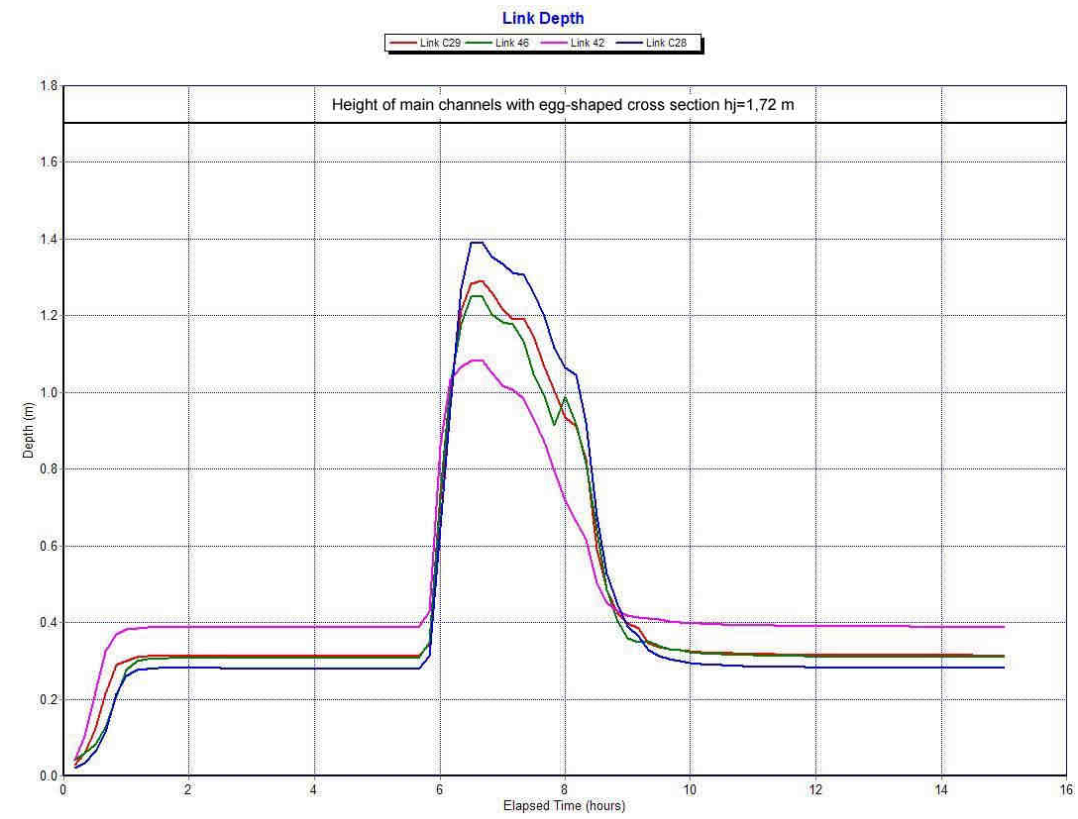

Fig. 3. Level of sewage in main canals, situated along the San river, estimated for the precipitation from 03.07.2006 - sewage system with Czuwaj storage reservoir 
In the simulations, which took into account in the sewer system the Czuwaj reservoir, a significant impact was observed on the reduction of water flow pressure in the main channels of the sewer system. The reservoir working together with tank overflow relief located ahead of it hydraulically unloaded the channels in which the waste water flows under pressure periodically. The results of these simulations for precipitation of 3 July 2006 are shown in Figure 3.

\section{Optimization of hydraulic system of Czuwaj reservoir}

In order to optimize the hydraulic system of the Czuwaj reservoir, optimization models were formulated for reservoirs with gravity-pump of types $G P W, G P D$ and $G P H$, whose cross-sections and characteristic design parameters are shown in Figures 4-6.

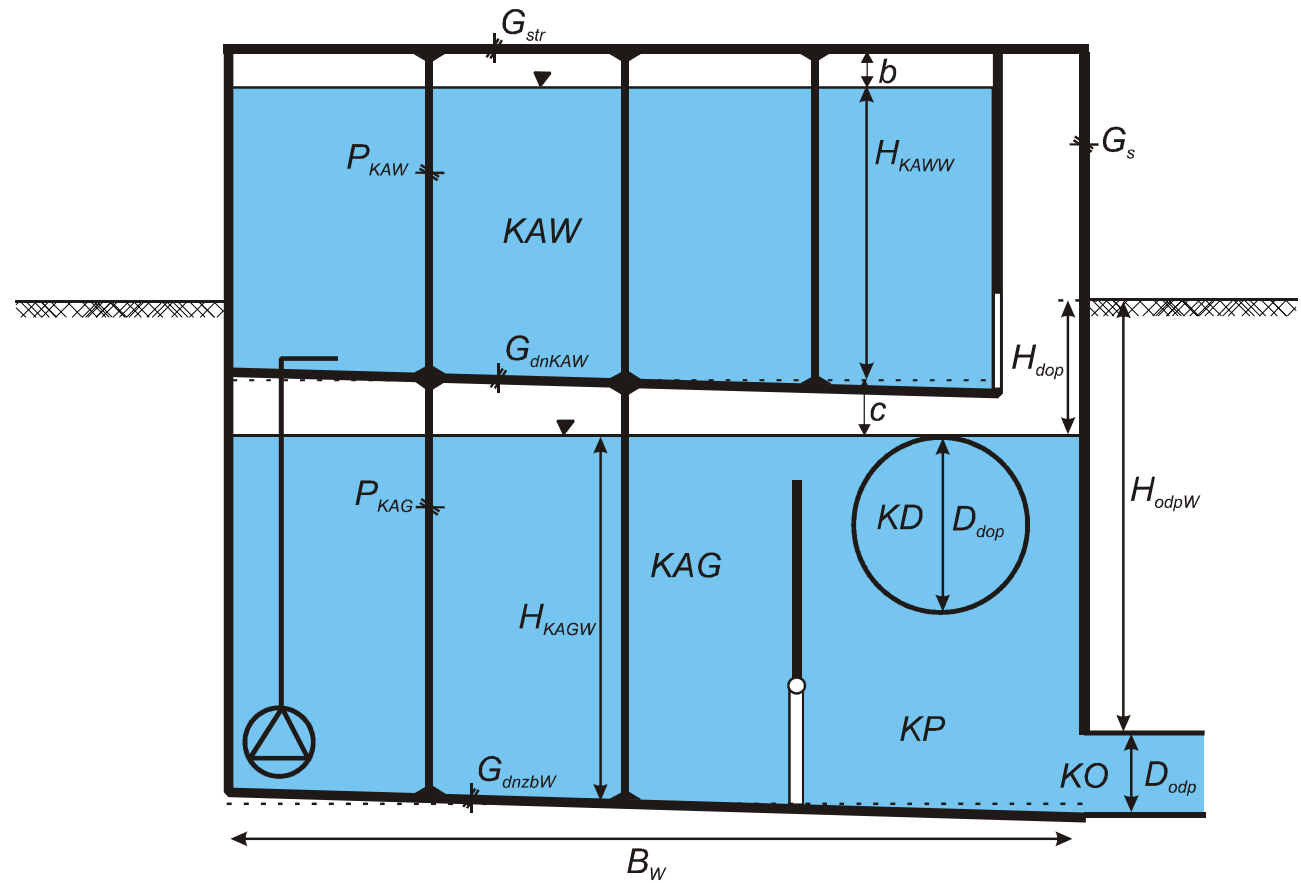

Fig. 4. Characteristic design parameters of gravity-pump storage reservoir type $G P W$ ( $K P$ - flow chamber, $K A G$ - gravity accumulation chamber, $K A W$ - upper accumulation chamber, $K D$ - inflow channel, $K O$ - outflow channel, $H_{K A W W}$ - maximum level of sewage in $K A W$ chamber in storage reservoir type $G P W, H_{K A G W}$ - maximum level of sewage in $K A G$ chamber in storage reservoir type $G P W, H_{o d p W}$ - level of the outflow channel, $H_{d o p}$ - level of the inflow channel, $D_{\text {dop }}$ - diameter of the inflow channel, $D_{\text {odp }}$ - diameter of the outflow channel, $G_{s}$ - thickness of the storage reservoir wall, $G_{s t r}$ - thickness of the storage reservoir floor, $G_{d n K A W}$ - thickness of the $K A W$ chamber bottom, $G_{d n z b W}$ - thickness of the storage reservoir $G P W$ type bottom, $P_{K A W}$ - cross-section of the pole in the $K A W$ chamber, $P_{K A G}$ - cross-section of the pole in the $K A G$ chamber)

In solving the complex decision making problem of selecting the optimal hydraulic system for the Czuwaj reservoir a single objective optimization method was used. The 
criterion for selection of the optimal solution was the least Life Cycle Cost (LCC) the construction and operation of the reservoir in the sewer system throughout the existence of the facility, which describes the relation (1). For the analyzed gravity-pump reservoirs general and specific models of LCC cost were developed:

$$
L C C=K_{I}+\sum_{t=1}^{T} K_{E}\left(\frac{1}{(1+r)^{t}}\right)
$$

where: $K_{I}$ - total investment for the construction of the reservoir [zl]; $K_{E}$ - annual operating costs associated with the operation of the reservoir in the sewer system [zl]; $T$ - the life of the reservoir in [years]; $t$ - subsequent year of operation of the tank [-]; $r$ - the discount rate $[-]$.

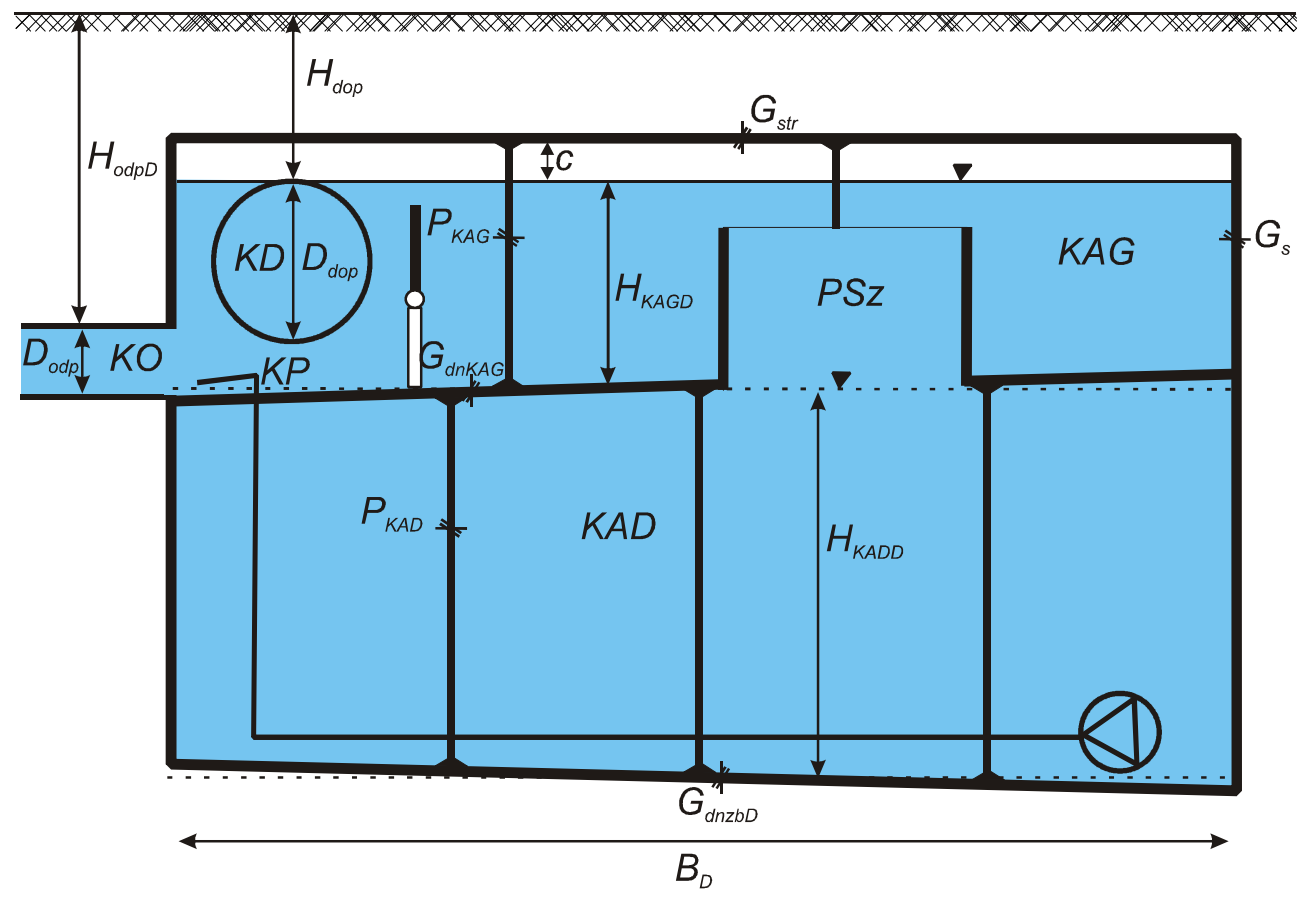

Fig. 5. Characteristic design parameters of gravity-pump storage reservoir type $G P D$ (KAD - lower accumulation chamber, $H_{K A D D}$ - maximum level of sewage in $K A D$ chamber in storage reservoir type $G P D, H_{K A G D}$ - maximum level of sewage in $K A G$ chamber in storage reservoir type $G P D$, $H_{o d p D}$ - level of the outflow channel, $H_{d o p}$ - level of the inflow channel, $G_{d n z b D}$ - thickness of the storage reservoir $G P D$ type bottom, $P_{K A D}$ - cross-section of the pole in the $K A D$ chamber)

The total investment costs for reservoir construction include expenditures for purchase of land for the investment, the cost of carrying out earthworks, expenses earmarked for constructing the storage reservoir and expenses resulting from equipping the tank and capital expenditures of installing the sewerage network located under the tank. The total investment $K_{I}$ can be described by the relation: 


$$
K_{I}=K_{\text {ziem }}+K_{r z}+K_{k}+K_{w}+K_{\text {sieci }}
$$

where: $K_{\text {ziem }}$ - capital expenditures for the purchase of land for the investment [zl]; $K_{r z}$ - capital expenditures allocated to the construction work connected with the construction of the reservoir [zl]; $K_{k}$ - investments aimed at constructing the storage reservoir [zl]; $K_{w}$ - investments intended to equip the reservoir with the necessary installations [zl]; $K_{\text {sieci }}$ - capital expenditures for the construction of the sewerage network located below the reservoir $[\mathrm{zl}]$.

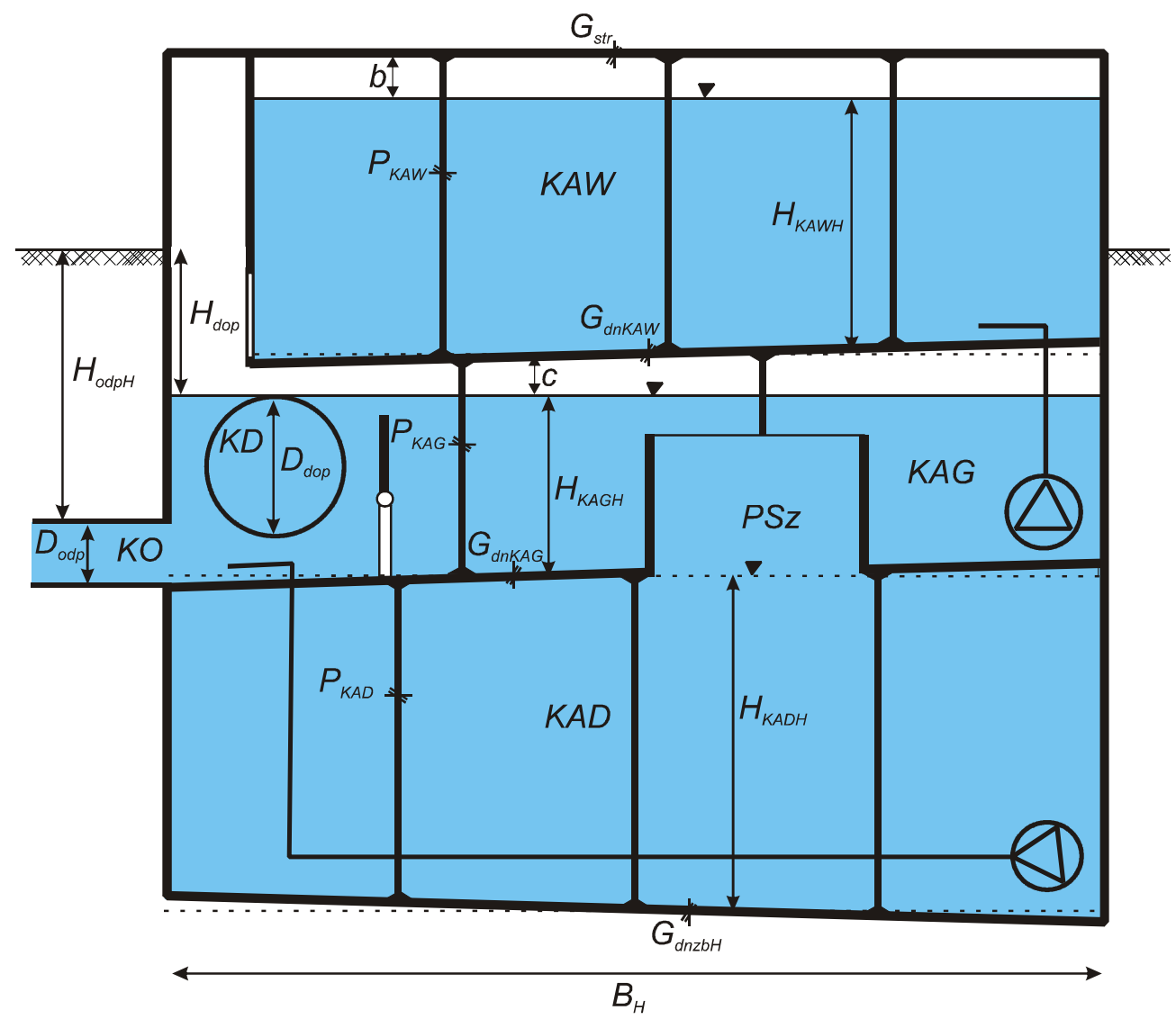

Fig. 6. Characteristic design parameters of gravity-pump storage reservoir type $G P H\left(H_{K A W H}\right.$ - maximum level of sewage in $K A W$ chamber in storage reservoir type $G P H, H_{K A D H}$ - maximum level of sewage in $K A D$ chamber in storage reservoir type $G P H, H_{K A G H}$ - maximum level of sewage in $K A G$ chamber in storage reservoir type $G P H, H_{o d p H}$ - level of the outflow channel, $G_{d n z b H}$ - thickness of the storage reservoir GPH type bottom)

In turn, the variable operating costs of the $K_{E}$ reservoir include the cost of electricity used for pumping transport of the water during the process of filling and emptying of storage chambers, the cost of cleaning the chambers of sewage sludge, the cost of 
breakdowns and replacement of pumps and service charges. The total cost is described by the equation:

$$
K_{E}=K_{p}+K_{c z}+K_{a}+K_{w y m}+K_{o b}
$$

where: $K_{p}$ - the cost of pumping transporting during the process of filling and emptying the storage chambers of the reservoir [zl]; $K_{c z}$ - the cost of cleaning the storage chambers of the reservoir [zl]; $K_{a}$ - the cost of breakdowns [zl]; $K_{\text {wym }}$ - the cost of replacing sewage pumps [zl]; $K_{o b}$ - the cost of servicing [zl].

Next the overall cost models described by equations (3) and (4) were developed and detailed to give the overall LCC cost models for all the analyzed reservoirs.

In a further stage of the study LCC cost models were transformed using the mathematical programming language: A Mathematical Programming Language (AMPL) in optimization models.

In the optimization model a set of decision variables were developed, in which were sought geometric parameters that determine the lowest LCC of the Czuwaj reservoir.

On the basis of the design documentation of the existing sewerage system and data obtained from the hydrodynamic model simulation for the catchment area of the Zasanie district the necessary parameters for optimization models were obtained, which are presented in Table 1.

Table 1

Constant parameters of optimization models of the gravity-pump storage reservoirs characterized the Czuwaj storage reservoir

\begin{tabular}{|c|c|c|}
\hline Parameter & Measurement units & Value \\
\hline Capacity of Czuwaj reservoir $V_{z b C z}$ & {$\left[\mathrm{~m}^{3}\right]$} & 6100 \\
\hline Diameter of inlet channel to the Czuwaj reservoir $D_{d o p C z}$ & {$[\mathrm{~m}]$} & 2 \\
\hline Diameter of outflow channel from the Czuwaj reservoir $D_{o d p} C z$ & {$[\mathrm{~m}]$} & 1.2 \\
\hline Depth of inlet channel to the Czuwaj reservoir $\mathrm{H}_{d o p C z}$ & [m] & 2.35 \\
\hline Depth of outflow channel from the Czuwaj reservoir $H_{o d p C z}$ & {$[\mathrm{~m}]$} & 3.2 \\
\hline Length of outflow channel from the Czuwaj reservoir $L_{p r z l C z}$ & [m] & 650 \\
\hline
\end{tabular}

Other parameters of optimization models were related to the unit prices of individual materials and construction, and the dimensions of the basic components of reservoirs.

\section{Analysis of the results obtained}

Taking into account the input data to the optimization models of reservoirs and determined limits and ranges of acceptable values of decision variables, calculations were made in order to select the optimal hydraulic system for the Czuwaj reservoir. The study was conducted on optimization models of reservoirs of type GPW, GPD and GPH.

The results obtained in the optimal design parameters of the Czuwaj reservoir depending on the hydraulic system of the tank are shown in Table 2. It also provides the value of the LCC cost, on the basis of which the choice of the optimal solution of the hydraulic system Czuwaj reservoir was made.

Clearly we can say that for the analyzed period $T=30$ years and for local investment conditions the optimal system for the reservoir is a GPD type hydraulic gravity-pump system. 
Geometric parameters of the Czuwaj storage reservoir and the LCC costs depending on the hydraulic system of the tank

\begin{tabular}{|c|c|c|c|c|c|}
\hline \multirow[b]{2}{*}{$\begin{array}{l}\text { Type of hydraulic } \\
\text { system for reservoir }\end{array}$} & \multicolumn{4}{|c|}{ Design parameters for Czuwaj reservoir } & \multirow[b]{2}{*}{$\begin{array}{c}\text { Costs } \\
\text { LCC }[\mathrm{zl}]\end{array}$} \\
\hline & $\begin{array}{c}\text { Internal length of } \\
\text { Czuwaj reservoir } \\
\quad-L_{C z}[\mathrm{~m}]\end{array}$ & $\begin{array}{c}\text { Internal width of } \\
\text { Czuwaj reservoir } \\
\quad-B_{C z}[\mathrm{~m}]\end{array}$ & \begin{tabular}{|c|} 
Maximum \\
wastewater \\
filling in \\
chamber $K A W$ \\
$-H_{K A W C z}[\mathrm{~m}]$
\end{tabular} & $\begin{array}{c}\text { Maximum } \\
\text { wastewater } \\
\text { filling in } \\
\text { chamber } K A D \\
-H_{K A D C z}[\mathrm{~m}]\end{array}$ & \\
\hline$G P W$ type reservoir & 29.42 & 29.42 & 5 & - & 8751047 \\
\hline$G P D$ type reservoir & 29.42 & 29.42 & - & 5 & 6436117 \\
\hline GPH type reservoir & 22.49 & 22.49 & 5 & 5 & 10422378 \\
\hline
\end{tabular}

In present times, thanks to the development of new technologies and the availability of more durable materials, there is a tendency for the design and construction of technical infrastructure to be characterized by greater durability and longer life. Therefore, the studies also calculated LCC for the Czuwaj reservoir for the analysis period $T$ equals 50, 75 and 100 years. The study was conducted in developed working models for optimization of gravity-pump reservoirs.

In order to determine the value of capital expenditure $K_{I}$ and operating costs $K_{E}$ in the total cost of the Czuwaj reservoir LCC calculations were performed for each of these cost categories. Determination of the $K_{E}$ operating costs at $T$ years of functioning allows the decision-maker at the stage of investment decision-making to select the optimal solution from among the options of reservoirs analyzed. Knowledge of these costs may significantly affect the choice of the most effective solution in terms of finance, it may happen that an optimal solution, for example, for $T=30$ years is no longer optimal for longer periods of analysis.

The results of research in this area for the analyzed hydraulic systems of reservoirs of types $G P W, G P D$ and $G P H$ are shown in Figures 7-9.

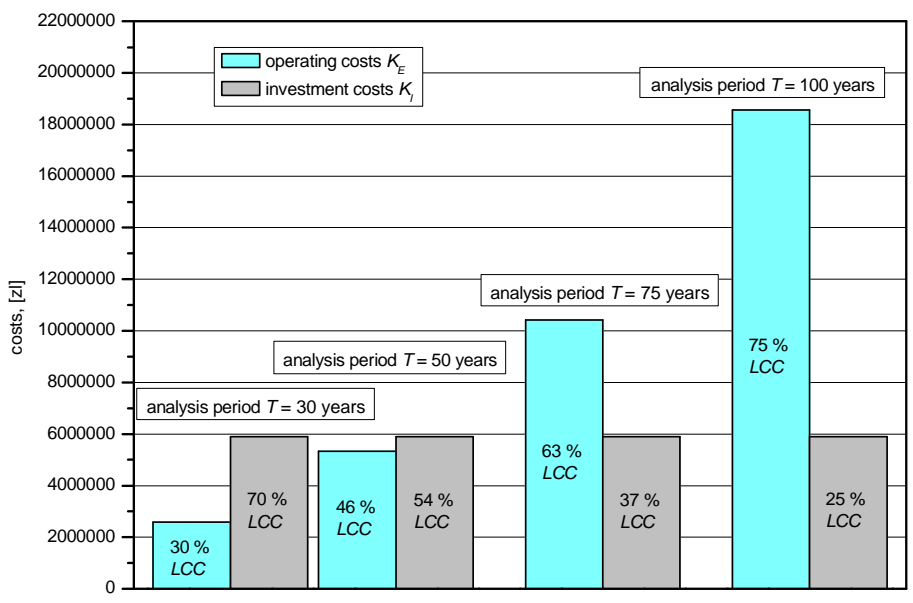

Fig. 7. Dependence of the cost of construction and operation of the Czuwaj reservoir on the working life of LCC for a GPW hydraulic system 


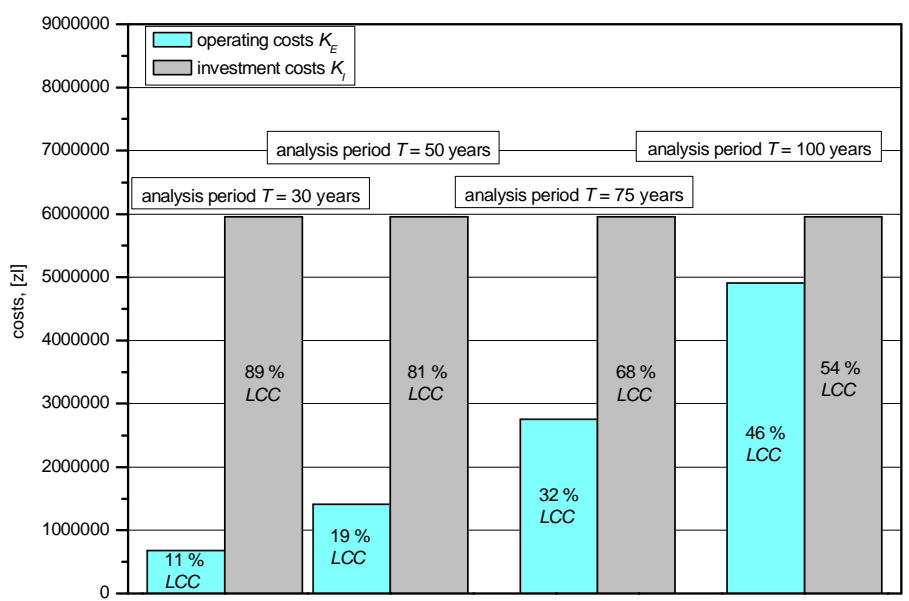

Fig. 8. Dependence of the cost of construction and operation of the Czuwaj reservoir on the working life of LCC for a GPD hydraulic system

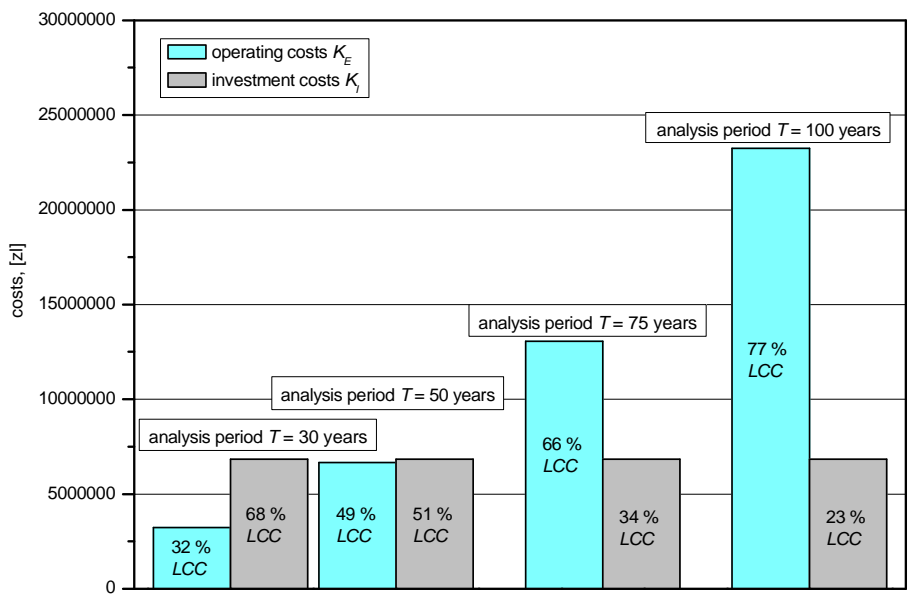

Fig. 9. Dependence of the cost of construction and operation of the Czuwaj reservoir on the working life of LCC for a GPH hydraulic system

Comparing the results for all models of optimization it can be stated that in terms of initial investment $K_{I}$ the cheapest reservoir is a $G P W$ type. However, given the operating costs the optimal hydraulic system for the Czuwaj reservoir is a GPD type gravity-pump.

The research on the actual catchment area of the Zasanie district confirmed the validity of the LCC analysis for the retention facilities that interact with the sewage systems for decades.

In making an investment decision on the basis of only calculations of initial investment $K_{I}$, as is often the case in tendering procedures, one can make mistaken choices the result of which, in the next few years, will be high operating costs $K_{E}$. 


\section{Summary and conclusions}

The results obtained allowed us to formulate basic conclusions of practical importance, namely, a GPD type gravity-pump reservoir is the optimal solution for the decision problem analyzed, since it is associated with some of the lowest LCC costs among the hydraulic system options under consideration for reservoirs. The initial investment costs that must be incurred on the construction of this reservoir are only slightly higher than the investment allocated to the implementation of the $G P W$ type gravity-pump reservoir. However, the operating costs associated with the operation of the GPD type reservoir are the lowest, and even during an analysis period of 100 years did not exceed the initial investment.

In the case of upgrading the sewage system, which, as shown by the hydrodynamic simulations, is necessary to ensure the proper functioning of the system, this proposal may provide valuable guidance to the Water and Sewage Company in Przemysl.

The study also showed that in the case of facilities with long operating hours, such as reservoirs, it is advisable to conduct a Life Cycle Cost financial analysis for a period longer than the period recommended by financial institutions. This conclusion is particularly important, since with the current state of technology and the high quality and durability of construction materials it is possible to provide many years of operation of reservoirs in the sewer system at the appropriate level of reliability. Therefore, retention facilities should be designed over a useful life of at least 50 years, and in justified cases up to 100 years.

\section{References}

[1] Carlson TN, Arthur ST. The impact of land use - land cover changes due to urbanization on surface microclimate and hydrology: a satellite perspective. Global and Planetary Change. 2000;25:49-65. DOI: 10.1016/S0921-8181(00)00021-7.

[2] Pauleit S, Ennos R, Golding Y. Modeling the environmental impacts of urban land use and land cover change - a study in Merseyside, UK. Landscape and Urban Planning. 2005;71:295-310. DOI: 10.1016/j.landurbplan.2004.03.009.

[3] Dallman S, Piechota T. Stormwater: Asset Not Liability. The Los Angeles and San Gabriel Rivers Watershed Council, Los Angeles: 1999. http://www.amazon.com/Stormwater-Liability-Suzanne-Dallman$\mathrm{Ph}-\mathrm{D} / \mathrm{dp} / 1453872329$.

[4] Chralowicz D, Dominguez A, Goff T, Mascali M, Taylor E. Infiltration of Urban Stormwater Runoff to Recharge Groundwater Used for Drinking Water: A Study of the San Fernando Valley. California: Project Report. University of California; 2001. http://www.esm.ucsb.edu/research/2001Group_Projects/ Final_Docs/stormwater_final.pdf

[5] Walsh CJ. Urban impacts on the ecology of receiving waters: a framework for assessment, conservation and restoration. Hydrobiology. 2000;431:107-114. DOI: 10.1023/A:1004029715627.

[6] Wong THF, Breen PF, Lloyd SD. Water sensitive road design - Design options for improving stormwater quality or road runoff. Technical report 00/01. Cooperative Research Centre for Catchment Hydrology; Melbourne: 2000. http://www.clearwater.asn.au/user-data/resource-files/technical200001.pdf.

[7] Roesner LA, Bledsoe BP, Brasher RW. Are best-management practice criteria really environmentally friendly? J Water Resources Plan Manage. 2001;May/June:150-154. http://ascelibrary.org/doi/abs/ $10.1061 / \% 28$ ASCE\%290733-9496\%282001\%29127\%3A3\%28150\%29.

[8] Paul M, Meyer J. Streams in the urban landscape. Annu Rev Ecol Syst. 2001;32:333-365. DOI: 10.1146/annurev.ecolsys.32.081501.114040.

[9] Rauch W, Bertrand-Krajewski J, Krebs P, Mark O, Schilling W, Schütze M, et al. Mathematical modelling of integrated urban drainage systems. Wat Sci Tech. 2002;45:81-94. http://modeleau.fsg.ulaval.ca/fileadmin/modeleau/documents/Publications/pvr289.pdf.

[10] Hatt BE, Fletcher TD, Walsh CJ, Taylor SL. The influence of urban density and drainage infrastructure on the concentrations and loads of pollutants in small streams. Environ Manage. 2004;34:112-124. DOI: 10.1007/s00267-004-0221-8. 
[11] Semadeni-Davies A, Hernebring C, Svensson G, Gustafsson L. The impacts of climate change and urbanisation on drainage in Helsingborg, Sweden: Combined sewer system. J Hydrology. 2008;350:100113. DOI: 10.1016/j.jhydrol.2007.05.028.

[12] Daniel MH, Montebelo AA, Bernardes MC, Ometto JP, de Camargo PB, Krusche AV, et al. Effects of urban sewage on dissolved oxygen, dissolved inorganic and organic carbon, and electrical conductivity of small streams along a gradient of urbanization in the Piracicaba River Basin. Water Air and Soil Pollut. 2002;136:189-206. DOI: 10.1023/A:1015287708170.

[13] Durchschlag A, Härtel L, Hartwig P, Kaselow M, Kollatsch D, Schwentner G. Total emissions from combined sewer overflow and wastewater treatment plants. European Water Pollut Control. 1991;6:13-23.

[14] Directive 2000/60/EC of the European Parliament and of the Council of 23 October 2000 establishing a framework for Community action in the field of water policy in 2000.

[15] Elliott AH, Trowsdale SA. A review of models for low impact urban stormwater drainage. Environ Modelling \& Software. 2007;22:394-405. DOI: 10.1016/j.envsoft.2005.12.005.

[16] Wong THF, Fletcher TD, Duncan HP, Coleman JR, Jenkins GA. A model for urban stormwater improvement conceptualisation. In: International Environ Modelling and Software Society Conference. Lugano, Switzerland; 2002. http://www.iemss.org/iemss2002/proceedings/pdf/volume\%20uno/ 358_wong.pdf.

[17] Ellis J. Infiltration Systems: A sustainable source-control option for urban stormwater quality management. Water and Environ J. 2000;14:27-34. DOI: 10.1111/j.1747-6593.2000.tb00222.x.

[18] Getter KL, Rowe DB. The role of extensive green roofs in sustainable development. Hort Sci. 2006;41(5):1276-1285. http://hortsci.ashspublications.org/content/41/5/1276.full.pdf.

[19] Hancock GS, Holley JW, Chambers RM. A field-based evaluation of wet retention ponds: how effective are ponds at water quantity control. J Amer Water Resour Associat. 2010;46:1145-1158. DOI: 10.1111/j.1752-1688.2010.00481.x.

[20] Dziopak J. Modelowanie wielokomorowych zbiorników retencyjnych w kanalizacji. Rzeszów: Oficyna Wydawnicza Politechniki Rzeszowskiej; 2004.

[21] Kisiel A. Kanalizacyjne zbiorniki z komorą podciśnieniową napełnianą układem pomp ssąco-tłoczących. Materiały XIV Konferencji Naukowo-Technicznej nt. Aktualne Problemy Gospodarki Wodno Ściekowej. Ustroń: 2004.

[22] Holland M. Computer Models of Wastewater Collection Systems. Cambridge: Harvard Water Resour Group; 1966.

[23] Liebman J. A heuristic aid for the design of sewer networks. J of the Sanitary Eng Division. 1967;4:81-90.

[24] Schutze M, Butler D, Bruce Beck M. Optimisation of control strategies for the urban wastewater system - an integrated approach. Water Sci and Technol. 1999;39. http://www.iwaponline.com/wst/ 03909/wst039090209.htm.

[25] Rauch W, Harremoës P. On the potential of genetic algorithms in urban drainage modeling. Urban Water. 1999;1. http://www.sciencedirect.com/science/article/pii/S1462075899000102\#.

[26] Boomgaard ME, Langeveld JG, Clemens F. Wastewater system optimization using genetic algorithms. World Water Congress; 2001. DOI: 10.1061/40569(2001)498.

[27] Fu G, Butler D, Khu S. Multiple objective optimal control of integrated urban wastewater systems. Environ Modelling \& Software. 2008;23. DOI: 10.1016/j.envsoft.2007.06.003.

[28] Fu G, Khu S, Butler D. Optimal distribution and control of storage tank to mitigate the impact of new developments on receiving water quality. J of Environ Eng. 2010;136. http://ascelibrary.org/doi/ abs/10.1061/\%28ASCE\%29EE.1943-7870.0000161.

[29] Stec A, Słyś D. Effect of development of the town of Przemysl on operation of its sewerage system. Ecol Chem Eng S. 2013;2:381-396. DOI: 10.2478/eces-2013-0028.

[30] Słyś D, Dziopak J. Development of mathematical model for sewage pumping-station in the modernized combined sewage system for the town of Przemyśl. Polish J Environ Stud. 2011;3:743-753.

[31] Dziopak J, Słyś D. The importance of planned reservoirs for the operation of the sewage system of the Zasanie district of the city of Przemysl and their impact on the status of the San River. Rzeszów; 2008.

[32] Słyś D, Stec A. Hydrodynamic modeling of the combined sewage system for the city of Przemyśl. Environ Protect Eng. 2012;4:99-112. DOI: 10.5277/EPE120409. 


\title{
OPTYMALIZACJA UKŁADU HYDRAULICZNEGO ZBIORNIKA RETENCYJNEGO ODCIĄŻAJĄCEGO HYDRAULICZNIE SIEĆ KANALIZACYJNĄ
}

\author{
Katedra Infrastruktury i Ekorozwoju, Wydział Budownictwa i Inżynierii Środowiska \\ Politechnika Rzeszowska
}

\begin{abstract}
Abstrakt: Przedstawiono problem optymalizacji układu hydraulicznego zbiornika retencyjnego Czuwaj, który zlokalizowany jest w systemie kanalizacji ogólnospławnej dzielnicy Zasanie miasta Przemyśl. W związku z tym, że w części lewobrzeżnej miasta występują największe przeciążenia hydrauliczne sieci kanalizacyjnej, podjęto działania mające na celu ograniczenie występowania tych niekorzystnych zjawisk. Opracowano koncepcję rozbudowy i modernizacji systemu kanalizacyjnego, uwzględniającą zastosowanie w tym systemie zbiorników retencyjnych, m.in. zbiornika Czuwaj, odciążających hydraulicznie sieć kanalizacyjną. W celu dokonania wyboru optymalnego układu hydraulicznego zbiornika retencyjnego Czuwaj opracowano modele optymalizacyjne wybranych typów grawitacyjno-pompowych zbiorników retencyjnych. Kryterium wyboru układu hydraulicznego zbiornika Czuwaj stanowiły najniższe koszty (Life Cycle Cost) budowy i funkcjonowania zbiornika retencyjnego w rozpatrywanym systemie kanalizacyjnym.
\end{abstract}

Słowa kluczowe: zbiorniki retencyjne, systemy kanalizacyjne, optymalizacja 